\title{
SELECTION OF EMPLOYEES IN THE METAL INDUSTRY BASED ON COMPETENCES, ON THE EXAMPLE OF A DESIGNER POSITION
}

\author{
Katarzyna SKRZYPEK*, Karol DĄBROWSKI** \\ University of Zielona Góra, Faculty of Mechanical Engineering, Zielona Góra, Poland \\ *e-mail: k.skrzypek@iizp.uz.zgora.pl \\ **e-mail: k.dabrowski@iizp.uz.zgora.pl
}

\begin{abstract}
The selection of an effective team of employees is crucial to proper management of the company. The success of the project often depends on the competencies of employees who carry out those projects. Therefore, the selection of the workers, whose competences complement each other in terms of subject matter, in terms of personality, and also in practical terms, is very important. This article presents the proposal of applying the FAHP (fuzzy analytic hierarchy process) and TOPSIS (technique for order preference by similarity to an ideal solution) methods as a tool to facilitate the management of human resources in the metal production factories based on the skills of employees.
\end{abstract}

Keywords: FAHP, TOPSIS, metal industry, selection of employees, competences, fuzzy analytic hierarchy process, technique for order preference by similarity to an ideal solution.

\section{$1 \quad$ Introduction}

Effective enterprise management depends on many factors occurring within the company, as well as on faster changing environment. Internal factors relate to the organization's resources, among which material, financial, information, and human resources are mentioned. The condition and quality of all company resources are considered as very important, but the subject literature emphasizes that human resources, today, play the most important role. Optimum utilization of other resources and skilful adaptation to the environment in which or to whom the organization works depends on the employees [10].

Team building is one of the first stages of the implementation of each task implemented in a manufacturing company. It is an essential activity for the proper implementation of the whole project. The substantive level of work depends on knowledge, experience, and personality of the team members cooperating in the given task; however, the proper implementation in accordance with an approved plan, depends on the leaders. The division of tasks, control in points relevant to the task, and monitoring the progress by performing the following steps are key elements in managing the process of implementation of a given task. "This is the art that requires ability to function in many job roles and to understand the meaning of the 'human factor' for the success of the project" [3]. "Individuals decide on everything - this statement repeated multiple times is always true when it comes to implementation of R\&D projects" [6].

This publication consists of two parts - theoretical and practical. In Section 2, the characteristics of the metal industry in Poland are described. Subsequent sections describes people - key positions from the standpoint of execution of tasks occurring in manufacturing companies in the metal industry and presents the methodology of establishing working groups in the described tasks using the FAHP (fuzzy analytic hierarchy process) and ANFIS methods.

\section{The metal industry in Poland}

The metal industry in Poland enjoys a history of development rich with traditions. The interest in this branch of business results from the access to raw material located within the Polish territory a significant source of iron deposits and non-ferrous metals. The first evidences for the existence of mines, extracting iron ore, and factories that process them date back to ancient times and are associated with the presence of the Celts in the Świętokrzyskie Mountains - "Near the village of Rudka, Celts built the largest iron ore mine complex in prehistoric Europe" [2]. Although the name of our country - Poland - is derived from the word 
"field," evidences of involvement in activities related to the work of which is a metal material, note that it is one of the key Polish specialties. The rapid development of metal industry in the Polish lands began in the first half of the nineteenth century. An important event affecting the further development of this sector in Poland was the incorporation of Upper Silesia after the plebiscites, where the metal industry has played an important role. The reforms of Eugeniusz Kwiatkowski carried out in the interwar period led to the construction of the Central Industrial District (CID), in which metal industry, mechanical engineering, chemical engineering, and aviation engineering were developed [11]. The extension of the CID was stopped by the outbreak of World War II.

Today, the biggest centres in Poland, which are focused on the metal industry, are: Bydgoszcz - Torun Industrial District, Wroclaw Industrial District, Warsaw Industrial District, Old-Polish Industrial Region, Bielsko Biała Industrial District, Krakow Industrial District, and Upper Silesian Industrial Region [11].
The difficulty is the determination of economic space in which businesses operate with the described industry, for example, the production of metal parts for cars, but not the assembly/production of cars. You can find companies engaged in metalwork qualified for the construction industry, for example, Balex Metal (the manufacturer of steel tiles) and Luk Metal Construction (the manufacturer of aluminium and construction facade). Therefore, the authors are seeking common denominator to determine what is the metal industry draw on Polish Classification of Activities.

By metal industries, the authors understand the industries located in the Polish Classification of Activities in the Section C - industrial processing, especially of division 25 and some of the companies operating within the divisions 28, 29, 30, and 33 . In the branch examined by the authors, it is necessary to distinguish metal industries that are engaged in, among others, metalworking, from the metallurgical sector, which, among others, focuses on smelters. Table 1 shows us a list of the largest Polish companies in the metal industry in 2012.

Table 1. Largest Polish companies in the metal industry in 2012 [4]

\begin{tabular}{|c|c|c|c|c|c|c|}
\hline $\begin{array}{c}\text { Top } \\
\text { 500 list } \\
\text { position }\end{array}$ & Name & $\begin{array}{c}\text { Revenues } \\
\text { from sales } \\
\text { [PLN '000] }\end{array}$ & $\begin{array}{c}\text { Total income } \\
\text { [PLN '000] }\end{array}$ & $\begin{array}{c}\text { Gross } \\
\text { profit } \\
\text { [PLN '000] }\end{array}$ & $\begin{array}{c}\text { Net profit } \\
\text { [PLN '000] }\end{array}$ & $\begin{array}{c}\text { Number } \\
\text { of employees }\end{array}$ \\
\hline 44 & $\begin{array}{c}\text { Grupa Can-Pack SA, } \\
\text { Kraków }\end{array}$ & $4,545,498$ & $4,598,108$ & 319,032 & 268,963 & 3,808 \\
\hline 70 & $\begin{array}{c}\text { Fiat Powertrain Techno- } \\
\text { logies Poland } \\
\text { Sp. z o.o., Bielsko-Biała }\end{array}$ & $3,440,421$ & No data & No data & No data & 1,130 \\
\hline 90 & $\begin{array}{c}\text { CMC Poland Sp. z o.o., } \\
\text { Zawiercie }\end{array}$ & $3,084,833$ & $3,104,325$ & No data & No data & 1,957 \\
\hline 125 & $\begin{array}{c}\text { CNH Polska Sp. z o.o., } \\
\text { Płock }\end{array}$ & $2,307,878$ & $2,344,066$ & 245,213 & 197,054 & 1,233 \\
\hline 152 & GK Stal Produkt SA & $1,808,703$ & $1,826,499$ & 77,145 & 59,834 & 2,668 \\
\hline
\end{tabular}

About how important is this sector for Polish industry confirms information that over $20 \%$ of all enterprises in the manufacturing sector is metal industry [5].

The analysis of the data contained in the report on the condition of the small- and medium-sized enterprises (SMEs) in Poland. In 2011-2012, in relation to Section $\mathrm{C}$, industrial enterprise, which con- tains, among others, businesses in the metal industry, shows that in 2012, in this section, 39,000 new companies were created $(7.5 \%$ of total newly created, in 2012, companies), and the number of liquidated companies in 2012 from the industrial processing sector was 25,600 (8.2\% of all companies liquidated in 2012) [13]. In industry, large companies focus mainly on manufacturing $(47.4 \%$ of large entities operates in this sector) [13]. The involvement 
of SMEs in industrial activity is $10.6 \%$ (the largest percentage of SME involvement in the exercise of service activities is $46.5 \%$ ) [13].

The involvement of SMEs in industrial activity is $10.6 \%$ (the largest percentage of SME involvement in the exercise of service activities - 46.5\%) [13].

The most dynamic growth is allocated to small and medium-sized enterprises (SMEs). Currently, this sector represents $99.8 \%$ of the total enterprises and generates $47.3 \%$ of gross domestic product (GDP) and employs 6.3 million people, representing
$70.2 \%$ of jobs in Polish enterprises [13]. The structure of the number of working people in SMEs in Poland in 2011 by the section of PKD - industry was $31.4 \%$ [13]. To illustrate the potential of the surveyed companies, it should be provided that the output sold in 2012 for industrial processing section was 1018710 million zloty. More detailed data on sold production for this section is shown in the Table 2.

Table 2. Data on sold PCA section industrial processing [13]

\begin{tabular}{|l|c|c|}
\hline \multicolumn{1}{|c|}{ Department } & $\begin{array}{c}\text { The percentage of sold industry } \\
\text { production in 2012 }\end{array}$ & $\begin{array}{c}\text { Production sold in million zloty } \\
\text { in 2012 }\end{array}$ \\
\hline Manufacture of metal & $6.6 \%$ & 79846 \\
\hline $\begin{array}{l}\text { Manufacture of machinery } \\
\text { and equipment }\end{array}$ & $3.2 \%$ & 38308 \\
\hline $\begin{array}{l}\text { Manufacture of motor vehicles, } \\
\text { trailers and semi-trailers }\end{array}$ & $8.6 \%$ & 104363 \\
\hline $\begin{array}{l}\text { Manufacture of other transport } \\
\text { equipment and devices }\end{array}$ & $1.4 \%$ & 17250 \\
\hline
\end{tabular}

From the interesting information showing the size of the industry, you can get acquainted with the report in the production of selected products from the metal industry in 2012.

Table 3. Production of selected products from the metal industry in 2012 [13]

\begin{tabular}{|l|c|}
\hline \multicolumn{1}{|c|}{ Product } & Quantity \\
\hline Steel tubes & 582 thousand tons \\
\hline Bearings & 206 million pieces \\
\hline Vehicle & 540 thousand pieces \\
\hline
\end{tabular}

Potential and needs of the Polish market in terms import / export ratio of selected products in this inof products produced in facilities qualified for the dustry. metal industry highlight the comparative data on

Table 4. Comparison of import to export of products in million zloty in 2012 in selected sections, the combined nomenclature $(\mathrm{CN})$, corresponding to the range of the metal industry [13]

\begin{tabular}{|l|c|c|}
\hline \multicolumn{1}{|c|}{ Product } & Import [mIn PLN] & Export [mIn PLN] \\
\hline No precious metals and pieces from them & 66,886 & 70,087 \\
\hline $\begin{array}{l}\text { Machinery and electronic and electromechanical appli- } \\
\text { ances }\end{array}$ & 142,107 & 141,479 \\
\hline Transportation equipment and devices & 63,882 & 85,516 \\
\hline
\end{tabular}


Industry defined as metal industry - is a welldeveloping industry increasingly open to innovation. Data published by the CSO show that among large enterprises is more business than innovators among SMEs, "In addition to insufficient financial and human resources, the innovativeness of SME (introduction of a new process, product or idea in the organization) is limited by: lack of innovative culture, insufficient leadership skills in managing innovation, risk aversion, lack of recognition by management of the creative possibilities of employees, insufficient knowledge about technology, market and modern management methods. On the other hand, it is pointed out that smaller companies compared with large, are characterized by: greater flexibility in adapting to changing market conditions, less bureaucracy and a lack of conflicts of objectives at the level of the owner - manager" [5]. To exist in the structures of SMEs, permanent efforts to improve innovation in addition to technological resources, machinery, and financial services are important factors: the attitude of management, employee involvement, and cooperation with other organizations [12].

The authors such as Karbownik A., Michna A., Męczyńska A., Kmieciak R. suggest that "due to the nature of SMEs the transfer of research results in large organizations, which is why similar studies should be conducted for SMEs is not explicitly authorized. In addition, the existing studies do not take into account the specific characteristics of a specific industry, in particular the metal industry, and various types of innovation: product and technological types $(\ldots) "[5]$.

\section{Constructor. Product developer}

Customer needs make the proposed product of high quality and advanced technology. After a period in which growth was seen only through the prism of existing technologies, increasing emphasis is placed on an intangible asset which are competences of employees. The basic elements of competencies are knowledge and skills [10]. Owning to the increased interest in this aspect, the emphasis on building effective work teams was increased.
One of the key sections in the factory is the section of technical preparation of production. Actions taken by this section focuses on the stages [1]:

- studies and research,

- the structural preparation of production (or how to make the product?),

- technological preparation of production (i.e., what constitutes a product?),

- organizational preparation of production.

- start-up of production,

- organization of sales and service.

Constructors are responsible for actions taken in a step. These employees develop the product, that is, they. give it shape. Owing to the very important position that they occupy in the factories of the metal industry for the purposes of this study, this position was selected.

\section{$4 \quad$ FAHP Method}

FAHP (fuzzy analytic hierarchy process) is the method of fuzzy analytic hierarchy process is based on AHP method, which is widely used in the development of decision-making models. FAHP uses experts opinions in order to establish the weighting factors that determine the validity of features and, additionally, eliminates the features of least importance, when it comes to question of linear ordering of objects. The importance of a feature in this case is established on the basis of fuzzy opinions of experts, the so-called, soft opinions, which are more viable than hard opinions [9].

\section{TOPSIS Method}

TOPSIS (technique for order preference by similarity to an ideal solution) method is a statistical process leading to linear ordering of objects described by metric and nonmetric features - professional order [9]. This method is used to establish order and rank of various alternatives [7]. 


\section{$6 \quad$ Research methodology}

The assessment procedure for the selection of staff necessary to perform orders in the metal industry, for example, the position of the constructor, is based on FAHP, which is the method used to solve multicriteria decision-making problems. This method proceeds by the following steps.

\section{- Stage 1}

Construction of a hierarchical decision-making scheme. In this process, hierarchical decisionmaking scheme is constructed, which consists of a main goal, intermediate objectives, and tasks. The main objective is placed on the top of the hierarchy, which consists of several subobjectives, which are its specific expression.

The next level of decision-making diagram form a task in which the implementation is necessary to achieve the low-priority objectives. Tasks can also be distributed to subordinates operation. The deci- sion scheme is built with several levels in which the number is dependent on the degree of generality, which wants to keep in the discussion. The main objective and goals and subtasks should be interrelated

- Stage II

The comparison of pairs of tasks within the subordinate objective. At each level of the hierarchy, the validity of decision elements are compared in pairs using the fuzzy nine-point scale (Table 1). These comparisons are analyzed based on its importance in the decision making. Using the scale, the comparisons of importance of lower priority are made, in regards to main objective and tasks in the scope of every lower-priority objective (Table 1). The pairwise comparisons of importance of critical elements on each level of hierarchy are conducted by professionals (decision makers) who are directly involved in careful decision-making process.

Table 5. The nine-grade evaluation scale of importance of pairwise elements [8]

\begin{tabular}{|c|c|c|}
\hline $\begin{array}{l}\text { The superiority of importance of } \\
\text { critical elements }\end{array}$ & Explanation & $\begin{array}{l}\text { Priority Scales } \\
(\widetilde{\boldsymbol{a}}=(\boldsymbol{l}, \boldsymbol{m}, \boldsymbol{u}))\end{array}$ \\
\hline Equivalence & $\begin{array}{l}\text { Both factors contribute equally to achieve the objec- } \\
\text { tive. }\end{array}$ & $\tilde{1}=(1,1,1)$ \\
\hline Poor or moderate & $\begin{array}{l}\text { Importance does not convince or poor priority of one } \\
\text { factor over another factor. }\end{array}$ & $\tilde{3}=(1,3,5)$ \\
\hline Important, fundamental Strong & $\begin{array}{l}\text { Fundamental or strong meaning, or strong priority of } \\
\text { one factor over other factors. }\end{array}$ & $\tilde{5}=(3,5,7)$ \\
\hline Vast or very strong & $\begin{array}{l}\text { Vast meaning or very strong priority of one factor } \\
\text { over other factors }\end{array}$ & $\tilde{7}=(5,7,9)$ \\
\hline Total & $\begin{array}{l}\text { Total meaning or total priority of one factor over } \\
\text { others. }\end{array}$ & $\widetilde{9}=(7,9,9)$ \\
\hline $\begin{array}{l}\text { For comparisons compromising } \\
\text { between values stated above }\end{array}$ & $\begin{array}{l}\text { Sometimes there is a need for numerical interpolation } \\
\text { of compromising opinions, because there is no ap- } \\
\text { propriate vocabulary to describe them. That is the } \\
\text { reason for applying intermediate values between two } \\
\text { adjacent grades. }\end{array}$ & $\begin{array}{l}\tilde{2}=(1,2,4) \\
\tilde{4}=(2,4,6) \\
\tilde{6}=(4,6,8) \\
\tilde{8}=(6,8,9)\end{array}$ \\
\hline Transitivity of grades & $\begin{array}{l}\text { If a factor A has assigned one of the above grades, } \\
\text { during a comparison with a factor B, then factor B } \\
\text { has opposite value, when being compared to A factor. }\end{array}$ & $\begin{array}{c}\text { the inverse } \\
\text { of the above values }\end{array}$ \\
\hline
\end{tabular}


Comparisons of results are summarized in the form of fuzzy matrix of pairwise comparisons $\widetilde{\mathrm{A}}$ :

$$
\widetilde{\mathrm{A}}=\left[\widetilde{\mathrm{a}}_{\mathrm{kg}}\right]=\left[\begin{array}{ccc}
(1,1,1) & \ldots & \left(\mathrm{l}_{1 \mathrm{p}}, \mathrm{m}_{1 \mathrm{p}}, \mathrm{u}_{1 \mathrm{p}}\right) \\
\ldots & \ldots & \ldots \\
\left(\mathrm{l}_{\mathrm{p} 1}, \mathrm{~m}_{\mathrm{p} 1}, \mathrm{u}_{\mathrm{p} 1}\right) & \ldots & (1,1,1)
\end{array}\right]
$$

and where:

$$
\tilde{\mathrm{a}}_{\mathrm{kg}}=\left(\mathrm{l}_{\mathrm{kg}}, \mathrm{m}_{\mathrm{kg}}, \mathrm{u}_{\mathrm{kg}}\right), \widetilde{\mathrm{a}}_{\mathrm{gk}}=\tilde{\mathrm{a}}_{\mathrm{kg}}^{-1}=\left(\frac{1}{\mathrm{u}_{\mathrm{kg}}}, \frac{1}{\mathrm{~m}_{\mathrm{kg}}}, \frac{1}{\mathrm{l}_{\mathrm{kg}}}\right), \mathrm{k}, \mathrm{g}=1,2, \ldots, \mathrm{p}
$$

are assessments of $\mathrm{k} \neq \mathrm{g}$, $\tilde{\mathrm{a}}_{\mathrm{kg}}$ comparisons in pairs of importance of the duties under the sub-ordinate objective indicated by experts or are geometric average of the ratings of the expert group. The number $\tilde{\mathrm{a}}_{\mathrm{kg}}=$ $\left(\mathrm{l}_{\mathrm{kg}}, \mathrm{m}_{\mathrm{kg}}, \mathrm{u}_{\mathrm{kg}}\right)$ is called triangular fuzzy number, represented by three assessment: pessimistic $\mathrm{l}_{\mathrm{kg}}$, most likely $\mathrm{m}_{\mathrm{kg}}$ and optimistic $\mathrm{u}_{\mathrm{kg}}$.

- Stage III

The determination of the sum of the elements of each line of the matrix of fuzzy pairwise comparisons $\widetilde{A}$ and standardization of line sums through operations on fuzzy numbers:

$$
\widetilde{\mathrm{Q}}_{\mathrm{k}}=\left(\mathrm{l}_{\mathrm{k}}, \mathrm{m}_{\mathrm{k}}, \mathrm{u}_{\mathrm{k}}\right)=\sum_{\mathrm{g}=1}^{\mathrm{p}}\left(\mathrm{l}_{\mathrm{kg}}, \mathrm{m}_{\mathrm{kg}}, \mathrm{u}_{\mathrm{kg}}\right) \otimes\left[\sum_{\mathrm{k}=1}^{\mathrm{p}} \sum_{\mathrm{g}=1}^{\mathrm{p}}\left(\mathrm{l}_{\mathrm{kg}}, \mathrm{m}_{\mathrm{kg}}, \mathrm{u}_{\mathrm{kg}}\right)\right]^{-1}, \mathrm{k}=1,2, \ldots, \mathrm{p}
$$

\section{- Stage IV}

The calculation of the degree of the fuzzy number is greater than or equal to the number $\widetilde{\mathrm{Q}}_{\mathrm{k}}$, that is, $\widetilde{\mathrm{Q}}_{\mathrm{g}}$ using the $\widetilde{\mathrm{Q}}_{\mathrm{k}} \geq \widetilde{\mathrm{Q}}_{\mathrm{g}}$ equation:

$$
V=\left(\widetilde{Q}_{k} \geq \widetilde{Q}_{g}\right)=\mu_{\widetilde{Q}_{k}}(d)=\left\{\begin{array}{c}
1, \text { if } m_{k} \geq m_{g} \\
0, \text { if } l_{g} \geq u_{k} \\
\left(l_{g}-u_{k}\right) /\left(\left(m_{k}-u_{k}\right)-\left(m_{g}-l_{g}\right)\right), \text { in other cases }
\end{array}\right.
$$

where $\widetilde{\mathrm{Q}}_{\mathrm{k}}=\left(\mathrm{l}_{\mathrm{k}}, \mathrm{m}_{\mathrm{k}}, \mathrm{u}_{\mathrm{k}}\right)$ and $\widetilde{\mathrm{Q}}_{\mathrm{g}}=\left(\mathrm{l}_{\mathrm{g}}, \mathrm{m}_{\mathrm{g}}, \mathrm{u}_{\mathrm{g}}\right)$ are two fuzzy number, and $\mu_{\mathrm{Q}_{\mathrm{k}}}(\mathrm{d})$ degree of belonging $\mathrm{d}$ belongs to $\widetilde{\mathrm{Q}}_{\mathrm{k}}$ (Fig. 1).

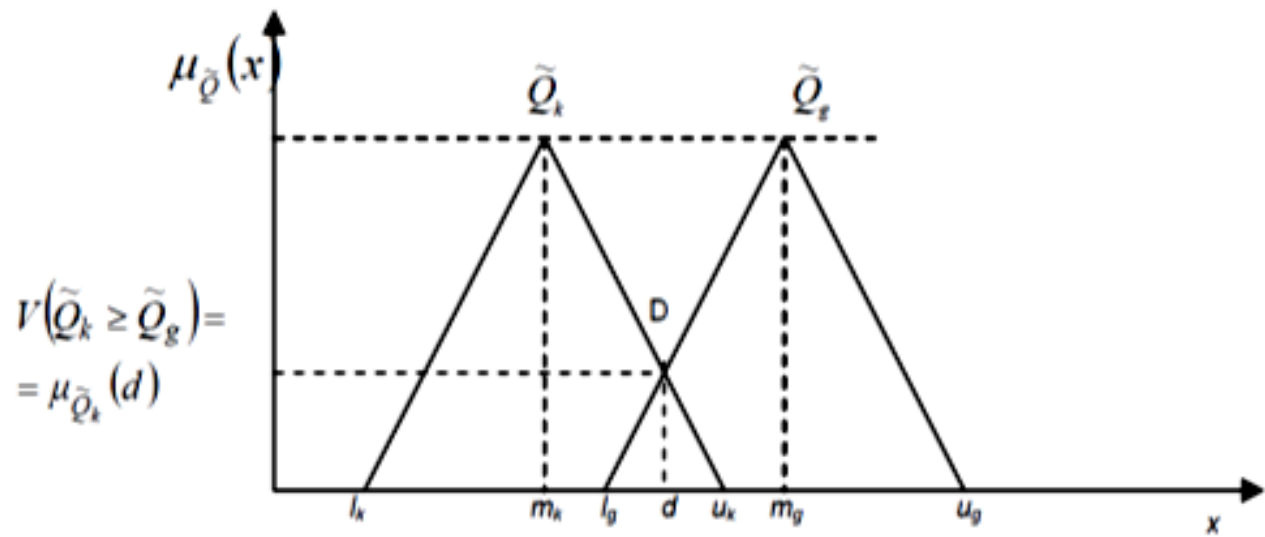

Figure 1. Determination of coordinates of the point of intersection between $\widetilde{Q}_{k}$ and $\widetilde{Q}_{g}[8]$ 


\section{- Stage V}

Indication of the smallest stage of the opportunities $V=\left(\widetilde{Q}_{k} \geq \widetilde{Q}_{g}\right)$ of fuzzy number $\widetilde{Q}_{k}$ to all other fuzzy numbers $(\mathrm{p}-1)$ as:

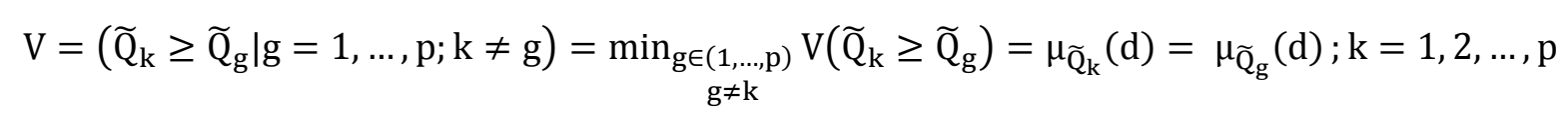

\section{- Stage VI}

Calculation of rate of contribution

$$
\mathrm{w}_{\mathrm{k}}^{(\mathrm{l})}=\mathrm{V}=\left(\widetilde{\mathrm{Q}}_{\mathrm{k}} \geq \widetilde{\mathrm{Q}}_{\mathrm{g}} \mid \mathrm{g}=1, \ldots, \mathrm{p} ; \mathrm{k} \neq \mathrm{g}\right) / \sum_{\mathrm{h}=1}^{\mathrm{p}} \mathrm{V}\left(\widetilde{\mathrm{Q}}_{\mathrm{h}} \geq \widetilde{\mathrm{Q}}_{\mathrm{g}} \mid \mathrm{g}=1, \ldots, \mathrm{p} ; \mathrm{h} \neq \mathrm{g}\right) ; \mathrm{k}=1,2, \ldots, \mathrm{p}
$$

in which they are taken as the weight of local tasks. Local priorities (weight) indicate the relative importance of the tasks within the subordinate objective.

\section{- Stage VII}

Counting the value of global priorities The values of global tasks represent their importance in relation to the main objective. The sum of all global values for tasks is 1 . It is calculated by multiplying the local priorities of tasks by the global priorities for the subordinate task

$$
\mathrm{w}_{\mathrm{k}}=\mathrm{w}_{\mathrm{k}}^{(\mathrm{l})} \cdot \mathrm{w}
$$

As a result, the size $w_{k}$ is taken as global priorities for tasks and presents as a vector

$$
\begin{aligned}
& \mathrm{W}=\left(\mathrm{w}_{1}, \mathrm{w}_{2}, \ldots, \mathrm{w}_{\mathrm{p}}\right)^{\mathrm{T}}, \\
& \text { where } \sum_{\mathrm{k}=1}^{\mathrm{p}_{\mathrm{j}}} \mathrm{w}_{\mathrm{k}}=\mathrm{w}, \mathrm{w} \geq 0
\end{aligned}
$$

Similarly, according to the stages II-VI local priorities (weight) for the purposes of a given subordinate objective can be calculated, where local and global weighting factors for the purpose of a subordinate objective are identical.

\section{- Stage VIII}

The determination of the $S_{i}$ characteristics using fuzzy TOPSIS method. Further steps are consistent with theoretical descriptions proposed by A. Luczak and F. Wysocki [9].

This will result in the determination of the distance of objects from the model of development and antmodel of growth and the enumeration with the typological classification of objects on the characteristics of synthetic accordance with the following principles [9]:

- Class I (very high level):

$$
\mathrm{S}_{\mathrm{i}} \geq \overline{\mathrm{S}}+2 \times \mathrm{S}_{\mathrm{c}}
$$

- Class II (high level):

$$
\overline{\mathrm{S}}+\mathrm{S}_{\mathrm{c}} \leq \mathrm{S}_{\mathrm{i}}<\overline{\mathrm{S}}+2 \times \mathrm{S}_{\mathrm{c}}
$$

- Class III (average-higher):

$$
\overline{\mathrm{S}} \leq \mathrm{S}_{\mathrm{i}}<\overline{\mathrm{S}}+\mathrm{S}_{\mathrm{c}}
$$

- Class IV (average-lower):

$$
\overline{\mathrm{S}}-\mathrm{S}_{\mathrm{c}} \leq \mathrm{S}_{\mathrm{i}}<\overline{\mathrm{S}}
$$

- Class V (low):

$$
\overline{\mathrm{S}}-2 \times \mathrm{S}_{\mathrm{c}} \leq \mathrm{S}_{\mathrm{i}}<\overline{\mathrm{S}}-\mathrm{S}_{\mathrm{c}}
$$

- Class VI (very low):

$$
\mathrm{S}_{\mathrm{i}}<\overline{\mathrm{S}}-2 \times \mathrm{S}_{\mathrm{c}}
$$

where:

$\bar{S}$ - is the arithmetic mean of the values from the synthetic characteristic,

$\mathrm{S}_{\mathrm{c}}-$ is their standard deviation.

\section{Conclusions and future work}

The purpose of this paper is to present the issue of effectiveness of the method of FAHP for building employee teams, for example, the position of the constructor. The studies attempt to portray this issue in a broader aspect of creating an effective business management tools in an environment, where the economy is based on knowledge of its existence.

It was found that the method of FAHP in preparing the team of employees is possible to implement in various organizations, including in factories in the metal industry. The way in which the recruitment was carried out seems to be rather a work of chance 
often based on subjective opinions and not on any indepth comparative analysis of the candidates. To change this situation, the use of the method of FAHP supplemented by a system of TOPSIS is proposed.

The application of the current procedure based on FAHP and TOPSIS must be preceded by an appropriate research material. This requires proper development of research tools. The right seems to be a survey form that contains a set of questions concerning the definition of the list of competencies necessary for the job of a constructor, together with the opinions of experts defining the "value" of individual data. It is important to note that the form in which questions and answers are included must comply with the requirements that impose the use in data analysis apparatus of fuzzy sets. The construction of such a tool and a presentation of the possibilities of its practical verification will be the subject of further studies.

\section{$8 \quad$ References}

[1] Brzeziński M. - Podstawy metodyczne projektowania rozruchu nowej produkcji. PWN, Warszawa, 1996.

[2] Davies N. - Boże Igrzysko, Warszawa, 2010.

[3] Gryzik A., Knapińska A., Tomczyńska A. - Zarzadzanie projektami badawczo - rozwojowym w sektorze przemystu, MNiSW, Warszawa 2012.

[4] http://www.lista500.polityka.pl/, 15.02.2015 r.

[5] Karbownik A., Michna A., Męczyńska A., Kmieciak R. - Innowacyjność produktowa i technologiczna $w$ matych $i$ średnich przedsiębiorstwach przemystu metalowego - koncepcja badań, Zeszyty naukowe Politechniki Śląskiej, SeSeria: Organizacja i Zarządzanie z. 56, 2011.
[6] Kisielnicki J. - Zarzqdzanie projektami badawczo - rozwojowymi, Wolters Kluwer SA, Warszawa 2013.

[7] Kun M., Topaloğlu S., Malli T. - Evaluation of wheel loaders in open pit marble quarrying by using the AHP and TOPSIS approaches, Arch. Min. Sci., Vol. 58, No 1, 2013.

[8] Łuczak A. - Ocena ważności czynników strategicznych $w$ gminie wiejskiej $z$ wykorzystaniem rozmytego analitycznego procesu hierarchicznego [in] Journal of Agribusiness and Rural Development 4 (6), Poznań 2012.

[9] Łuczak A., Wysocki F. - Porzqdkowanie liniowe obiektów $z$ wykorzystaniem rozmytych metod AHP $i$ TOPSIS, Przegląd Statystyczny, Zeszyt 1 $-2,2011$.

[10] Niewiadomski P., Dostani E. - Kompetencje wykonawcze $w$ procesie produkcyjnym na przykladzie praktycznym. Zarządzanie Przedsiębiorstwem, nr 1, 2013.

[11] Polska Agencja Informacji i Inwestycji Zagranicznych - Sektor metalowy w Polsce Wschodniej, Warszawa 2012.

[12] Rubio A., Aragón A. - SMEs Competitive Behavior: Strategic Resources and Strategies, Management Research, vol. 7(3), 2009.

[13] Tarnawa A., Zadura-Lichota P. - Raport o stanie sektora matych $i$ średnich Przedsiębiorstw w Polsce. W latach 2011-2012, PARP, Warszawa, 2013. 